\title{
Reflection of Learning Theories in Iranian ELT Textbooks
}

\author{
Hossein Hashem Neghad \\ Islamic Azad University, Khoy Branch, Iran \\ E-mail: Hossein535986@gmail.com
}

Doi:10.7575/aiac.alls.v.5n.2p.115

Received: 30/02/2014

URL: http://dx.doi.org/10.7575/aiac.alls.v.5n.2p.115

Accepted: 07/04/2014

\begin{abstract}
This study was undertaken to evaluate Iranian ELT English textbooks (Senior High school and Pre-University) in the light of three learning theories i.e., behaviourism, cognitivism, and constructivism. Each of these learning theories embedding an array of instructional strategies and techniques acted as evaluation checklist. That is, Iranian ELT English textbooks were evaluated in terms of instructional strategies and techniques cited in the related literature for each learning theory. The analysis of data in this descriptive study through frequency count and relative frequency revealed that the major principle of organization in Senior High school is the learning theory of behaviourism. Although Constructivism was observed to be the prominent learning theory in Pre- University English textbooks, combination of other learning theories were indicated. It was also indicated that cognitivism was rated as the second most important learning theory across all educational level. Analysis of the data through Chi-Square showed that reflection of learning theories in Iranian ELT textbooks is not by chance and the differences are significant with behaviourism on the one side, cognitivism in between and constructivism on the other side of continuum.
\end{abstract}

Keywords: Behaviourism, Cognitivism, Constructivism, Textbook Evaluation

\section{Introduction}

Education psychology as in the other areas of knowledge has evolved through a number of rise and fall within its short life. Within its journey, education psychology has been affected by some fashions and trends some of which had greater impact upon it. Tracing the wax and wane of education psychology and how learning theories emerged, connected and conflicted can shed light on one's evaluation and contribution to language teaching. (William and Burden, 1997). They stated that, late in the nineteenth century, discipline of psychology, which was in its germinal form, tried to assert itself as a science on a par with the natural sciences. This adaptation of the so called scientific method advocated an experimental methodology which is part of philosophical form of enquiry known as logical positivism.

Behaviorism as an approach to positivism is exemplified by the works of Bloomfield, Skinner, Thorndike and Watson. In their view, language learning like any other kinds of learning is simplified as the formulation of habits. This view stems from the work in psychology which saw the learning of any kinds of behavior based on the notion of stimulus and response (Mitchell and Myles, 1998). According to Mirhassani (2003), the basics of behaviorism can be examined through the works of Pavlov (1927); Skinner (1938); Thorndike (1898); Ebbinghaugh (1913).

Pavlov (1927, as cited in Mirhassani, 2003), as the first approach to associative learning, proposed the notion of signal learning, or classical conditioning to emphasize that the learner is associating an already available response with a new stimulus or signal. As the second approach to associative learning, skinner (1938, as cited in Brown, 2007) put forward the notion of operant conditioning. As Mirhassani stated this operant conditioning was also found in Thorndik's (1898) work with animal boxes, as well as in many other animal learning studies involving maze, compartments, lever and other devices in which a response is instrumental to a subsequent learning. Ebbinghaugh (1913, as cited in Mirhassani, 2003) revealed the third trend as the verbal association learning emerged. The intention of this fashion was to investigate the characteristics of association as a learned connection between one word and another.

Mirhssani (2003) adds chaining as another aspect to these three basics of learning situation. Chaining which is an individual association and connected in sequence is readily learned by animals as successive turn in a maze or by human as mental maze.

Since behaviorism ignored the significant role of learners and the cognitive or mental processes that they bring to the task of learning, the pre - eminent role of environment which was argued by skinner in shaping the child's learning and behavior lost the ground in the 1950s and more developmentalist views of learning such as Piaget's cognitive developmental theory, in which inner forces drive the child, in interaction with environment came into vogue. (Mitchell and Myles, 1998). As a result, cognitive psychologists became interested in the mental processes that are involved in learning and the way people build up and draw upon their memories. (William and Burden, 1997). However, the way in which human learning and memory is investigated varies greatly within cognitive psychology in which pendulum is moving from a theoretical framework based on cognitivism to a constructive framework. (Doolittle, 1998).

According to Mirhssani (2003), cognitivism which is defined as the scientific study of mental events takes the responsibility for acquiring, processing, storing and retrieving information. Therefore, the main emphasis of cogntivism is how information is processed and stored. With regard to storage system, Doolittle (1998), proposed that the idea of cognitivism or mind as computer. This idea was enhanced by Atkinson and Shiffrin's (1968, as cited in Doolittle, 1998) dual store information model which consists of two separate and distinct memory, short term memory and long term memory. In the same vein, Anderson (1995) attributed short tem memory to a temporary stage in which information is held by rehearsal. This process of rehearsal is responsible for transferring the information from short term memory to 
long term memory which is a permanent storage with an ultimate capacity. Another term which is frequently discussed in the realm of cognitivism is working memory. According to Anderson (1995), working memory is used to mean the information we currently have available in any of our memory for working on a problem. In other words, it refers to all transient information to which we currently have access.

Learning, memory and cognition as memory functions are the basic elements of cognitivism which involve intricate process that are organized under three different stages: acquisition, retention and retrieval (Doolittle ,1998). Doolittle continued that the acquisition process involves the initial creature of records and their associations. He stated that while the retention process is concerned with how these records decay over time and how various cues lose the ability to activate a memory records, the retrieval process is concerned with how current cues activate specific records.

Since cognitivism, as is evident, placed little or no emphasis upon the ways in which the individuals bring meaning to their world, constructivism as another perspective within cognitive psychology has deserved attention. Fosnot (1996, p. ix) defined constructivism as follow:

"Learning from this perspective is viewed as a self regulatory process of struggling with the conflict between existing proposal models of the world and discrepant new insights, constructing new representations and models of reality as a human meaning making venture with culturally developed tools and symbols, and further negotiating such meaning through cooperative social activity, discourse and debate.

Therefore, according to Doolittle (1998), constructivism can be observed as the active creation and negotiation of thought, ideas, and understanding as the result of experience that occur within a socio-cultural context. In line with his proposal, two crucial elements which led to separation of constructivism from cognitivism and paved the way for the constructivism were learner autonomy and wholistic perspective. Learner autonomy is the concept that learners are active participants in the learning process and ultimately responsible for their own learning. The wholistic perspective is a non reductionist approach that emphasizes learning in context.

As far as the implication of theoretical findings and positions of some schools of thought in pedagogy is concerned, behaviorist views of learning were taken up widely by language teachers and were a powerful influence on the development of the Audio Lingual approach to language teaching. As William and Burden (1997) stated the implication of behaviorism in ALM can be summarized as the process of providing learners with the stimuli in the form of small, sequential step to which learners responds to repetition or substitutions which is followed by teacher's reinforcement. Mechanical habit, instant error eradication, pattern drill, memorization of dialogue, choral repetition of structural drill can be some of the building blocks of this approach toward learning.

Moving from behaviourism to cognitivism was reflected in the acquisition of complex cognitive skills in pedagogy. Based on William and Burden's (1997) view, for a learner to become proficient, subskills of the complex cognitive tasks must be practiced, automatized, integrated, and organized into internal representations and rule systems are constantly restructured as proficiency develops. Therefore, it can be inferred that memory is particularly important in language learning. Oxford (1990) also proposed that chunking, rehearsal, mnemonics, meaningful learning, prior knowledge, summary, outlining, contextualization are among the strategies and techniques favored by cognitivism.

The implications of constructivist psychology, philosophy and epistemology to the characterization of constructivist learning environment present the challenge of synthesizing a large spectrum of somewhat disparate concepts. (Murphy, 1997). In the same way, Doolittle (1998) stated that constructivist pedagogy as the link between theory and practice suffers from the breadth of its theoretical underpinning. He argued that many theorists and practitioners e.g., Jonassen (1991) and Peveto (1997) have generated constructive pedagogies with an array of results which seem to share a set of core design but their peripheral principle vary greatly. In this regard, Matusevich (1995) has proposed a typical list of constructive programs and activities e.g., whole language, real worlds audiences, peer review, cooperative learning, authentic activities, inferencing, self evaluation etc.

Reflections of learning theories and values are emphasized by Hutchinson (1987) and Nunan (1988). They stated that materials which are the most prominent in the curriculum are not simply the everyday tool of language teacher but an embodiment of aim, value and methods of teaching and related theory. Therefore, materials are the most concrete manifestation of curriculum in action. While evaluation in general and textbook evaluation ,specifically, have been greatly emphasized (Atkinson, 2001; Ellis, 1997), Atai (2002) mentioned that any type of evaluation i.e., summative and formative is a missing link and Iranian ELT and ESAP curriculum suffers from incoherent system and mismatch between components.. Accordingly, this study has tried to evaluate Iranian ELT textbooks based on learning theories, namely behaviourism, cognitivism and constructivism. The present study, specifically, set out to determine the extent to which Iranian ELT textbooks reflect techniques and strategies of behaviourism, cognitivism and constructivism. The purpose of this study was to understand to what extent the strategies and techniques related with the referred learning theories are reflected in Iranian ELT textbooks.

\section{Method}

\subsection{Material}

To perform this evaluation study, the researcher closely examined Iranian ELT textbooks (Junior high school English textbook I and II; Senior high school I, II, III and Pre-university English textbook I and II). Iranian ELT textbooks are published by the Ministery of Education and are the main textbooks in national curriculum. While both junior high school English textbook I and II and Senior high school English textbook I, II, III are reprinted and used annually and have not been revised recently, Pre-university English textbook I and II were revised thoroughly in 2004.

\subsection{Procedure}

To evaluate Iranian ELT textbooks based on different learning theories (behaviorism, cognitivism and constructivism), the researcher devised a framework of instructional techniques and strategies to act as the evaluation checklist. In other 
words, the implication of these learning theories which are in the form of instructional techniques and strategies were used to form the basis of Iranian ELT textbook evaluation. This formulated evaluation checklist or instructional strategies and techniques were constructed based on the works in the related literature. Instructional strategies and technique related to the learning theory of behaviourism were borrowed from Richard and Rodgers (2001). Oxford (1990) and William and Burden's (1997) model were used for the instructional strategies and techniques related to cognitvism. Finally, instructional strategies and techniques for constructivism were taken from Doolittle (1998), Jonassen (1991, as cited in Doolittle, 1998) and Matusevich (1995). The implications of these learning theories were investigated across different educational levels (Junior High school; Senior High School and Pre University) to see which level is more influenced with which learning theories or a combination of them. Since the format of different lessons in each textbook is exactly the same, techniques are almost exactly repeated over. Therefore, the researcher considered a single occurrence of techniques in different section of a single lesson. For example, questions and answers as one of the behaviouristic techniques has been repeated in different sections of Junior High school English textbook II (Dialogue, Pattern, Oral Drill, Write it Down, and Speak Out) in all eleven lessons. Therefore, the frequency must be 55. But the researcher, focusing on the occurrence of this technique in different sections of a lesson, considered its frequency as five.

\section{Data Analysis}

To analyze the data in this study, frequency count, relative frequency and Chi-square analysis were utilized. The data was firstly presented in frequency count and relative frequency and then Chi- square analysis was employed to find out whether there is any significant difference between instructional strategies and techniques presented in Iranian ELT textbooks.

\section{Results and Discussions}

Table 1. shows the frequency count of learning theories, namely bahaviourism, cognitivism and constructivism in Iranian ELT textbooks.

Table 1. Frequency Count of Learning Theories Reflected in Iranian ELT textbooks

\begin{tabular}{llllllll}
\hline \multicolumn{7}{c}{ Iranian ELT Textbooks } \\
\hline Learning Theories & Junior I & Junior II & Senior I & Senior & Senior III & PRE-U I & PRE-U II \\
Behaviourism & 16 & 16 & 19 & 17 & 17 & 6 & 7 \\
Cognitivism & 5 & 5 & 4 & 6 & 5 & 10 & 10 \\
Constructivism & 0 & 0 & 1 & 1 & 1 & 19 & 18 \\
\hline
\end{tabular}

According to table 1, behaviorism is the focus of attention in Junior and Senior High school English textbooks while it has the least frequency count in Pre-university English textbooks. This table shows while constructivism has almost no role in Junior and Senior High school English textbook, it has the largest frequency count in Pre- university textbooks. As far as cognitivism is concerned, table 1 also indicates that this learning theory has its largest frequency count is in Pre-university textbooks.

Since Iranian ELT textbooks have almost exactly the same organization in each educational level, it may be more systematic and meaningful if the reflections of learning theories will be considered across educational levels .i.e., Junior High School; Senior High School level and Pre- University rather than each single textbook.

Table 2. Frequency Count of Learning Theories Reflected in Iranian ELT textbooks

\begin{tabular}{llll}
\hline & \multicolumn{2}{c}{ Iranian Educational Level } \\
\hline & Junior High school & Senior High School & Pre-University \\
Behaviourism & 32 & 53 & 13 \\
Cognitivism & 10 & 15 & 20 \\
Constructivism & 0 & 3 & 37 \\
\hline
\end{tabular}

Table 3. Relative Frequency of Learning Theories Reflected in Iranian ELT textbooks

\begin{tabular}{llll}
\hline \multicolumn{3}{c}{ Iranian Educational Level } \\
\hline & Junior High school & Senior High School & Pre-University \\
Behaviourism & $76.2 \%$ & $74.6 \%$ & $18.6 \%$ \\
Cognitivism & $23.8 \%$ & $21.2 \%$ & $28.6 \%$ \\
Constructivism & $0 \%$ & $4.2 \%$ & $52.8 \%$ \\
\hline
\end{tabular}

Table 2 and 3 indicate that behaviourism with the frequency count of 32 and relative frequency of $76.2 \%$ plays the largest role in Junior High school English textbooks. Cognitivism with the frequency of 10 and relative frequency of $23.8 \%$ is rated as the second learning theory in Junior High School English textbooks. Table 2 and 3 also illustrate that constructivism has no role in these textbooks.

The realization of learning theories in Senior High school English textbooks follow the same trend; that is, behaviourism with the frequency count of 53 and relative frequency of $74.6 \%$ is on the one side and constructivism with 
the frequency count of 3 and relative frequency 45 is on the other side. Cognitivism with the relative frequency of $21.2 \%$ is again rated as the second learning theory in these textbooks.

The distributions of learning theories change dramatically in Pre-university textbooks. That is, constructivism with the relative frequency of $52.8 \%$ and frequency count of 37 is the major principle for the organization of the textbooks and behaviourism with the frequency count of 13 and relative frequency of $18.6 \%$ is at the bottom of the list. Cognitivism is still considered the second most important learning theory.

To sum up, it can be said that while behaviourism is the major learning theory in Junior and Senior High school English textbooks, constructivism has been give no treatment. Cognitivism, however, received some minor attention. Combination of learning theories can be observed in Pre-university textbooks but the degree of emphasis can be respectively traced as $53 \%, 28 \%$ and $19 \%$ for constructivism, cognitivism and behaviourism.

Table 4. Chi-Square for the Distribution of Learning Theories in Iranian ELT Textbooks

\begin{tabular}{cl}
\hline$\chi$ & Critical value \\
\hline $77.2 *$ & 9.48 \\
\hline
\end{tabular}

Table 4 indicates that Chi-Square is far larger than critical value. That is significant differences exist in Iranian ELT textbooks with regard to the implications of learning theories. In other words, behaviourism is the main element of organization in Junior and Senior high school English textbooks and consrtructivism is the main learning theory for PreUniversity textbooks.

Reflection of learning theories in Iranian ELT textbooks can be in tandem with Jonnassen and McAleese (2005) and Schewier's (1995) views. Schewier (1995) elaborated on behaviourism, cognitivism and constructivism as what works where and how we should knit everything to gain at least some focus in our approach to instructional design. He stated that it is the circumstances surrounding the learning theory situation that help us decide which approaches to learning are most appropriate. In the same way Jonnasson and McAleese (2005) proposed that the predetermined, constrained and sequential materials are most suitable for introductory learning; that is, learners who have very little prior knowledge about a skill or content area. According to Jonnasson and McAleese (2005), advanced knowledge acquisition and expertise, however, are the stages in which constructivist approach would work. Therefore, the emphasis of behaviourism in Senior High school and Constructivism in Pre-University level can be considered in line with what the argument proposed by these educators.

In favor of cognitivism, Gange and Medsker (1996) stated that, it is imperative to design instruction in a way to establish learning. Training should support the cognitive processes of the brain by activating mental sets that affect attention and selective perception, enhance encoding by providing necessary organization for the new data, and maintain executive control that keeps the instruction going in the right direction. That is, establishing and employing effective learning strategies, for example, sequencing, organization and structuring are the key to successful encoding of information in long term memory. Accordingly, table 2 and 3 indicated that although cognitivism was not dealt with thoroughly, it was the learning theory which was rated as the second most important in all Iranian ELT textbooks.

\section{Conclusions and Pedagogical Implications:}

The results revealed that the major principle of organization in Junior and Senior High school was the learning theory of behaviourism while Pre-university textbooks oriented more toward constructivism. Although, reflection of learning theories may be justified based on what Schewier (1995) mentioned in terms of proficiency level, some points should be remembered with regard to Iranian curriculum development and learners' proficiency level. First, No smooth shift was observed from behaviourism to constructivism; since, learners are taught through instructional strategies and techniques of behaviourism in five years and suddenly in the last year of their educational program, they are faced with instructional strategies and techniques of constructivism. Second, under no circumstances, we can definitely determine learners' proficiency level based on their educational level. Different factors e.g., geographical position (whether one lives in a remote area or a big city), taking part in private institute, motivation, individual differences, etc can contribute to face learners with different proficiency level within the same educational level. Therefore, each learner will bring a different set of knowledge and experience to the classroom. It is, therefore, the teacher's responsibility to take into account different learners variables e.g., learners' proficiency level, learners' prior knowledge to select, adopt and present instructional strategies and tasks relevant to individuals.

Having involved in action research, teachers can fully avail themselves from the great benefits. They can have an in depth knowledge of the textbook organization, probable strengths and weaknesses of the textbooks and provide learners with supplementary material to reinforce their teaching. The learning activities presented in textbooks reflect the belief and value of curriculum developers. Teachers should act as an interface between the textbooks and learners to consider learners' need, foster the right climate for learning to take place, develop confidence and learners' individuality to be respected.

\section{References}

Anderson, J.R. (1995). Constructivism: Theory, perspective and practice. New York: Teacher College Press. Brown, D. (2007). Principles of language learning and teaching. New York: Pearson Education.

Atai, M.R. (2002). ESAP curriculum development in Iran: An incoherent educational experience. Journal of the Faculty of Letters and Humanities, 9 (3), 17-33.

Doolittle, P. (1998). Integrating constructivism and cognitivism. Retrieved from http://edpsychderver. ed.vt.edu/ research/ icc.html.

Ellis, R. (1997). The Empirical evaluation of teaching materials. ELT Journal, 51(1), 36-42.

Fosnot, C.T. (1996). Constructivism: Theory, perspective and practice. New York: Teacher College Press. 
Gagné, R. M., \& Medsker, K. L. (1996). The conditions of learning training applications. Florida: Harcourt Brace \& Company.

Hutchinson, T (1987). What's underneath? An interactive view of materials evaluation. In L. E Sheldon (Ed.), ELT textbooks and materials: Problems in evaluation and development (pp. 37-44 ). ELT Documents 126. London, UK: The British Council.

Matusevich, M. N. (1995). School reform: What roles can technology play in a constructive setting? Retrieved from http:// pixel.cs.vt.edu/fis/techcons.html/.

Mirhassani, A. (2003). Theories, approaches and methods in teaching English as a foreign language.Tehran: Zabankadeh Publication.

Mitchell, R., \& Myles, F. (1998). Second language learning theories. Oxford: OUP.

Murphy, E. (1997). Characteristics of constructive teaching and learning. Retrieved from http://cdli.ca/ elmurphy/ emurphycle3.html

Nunan, D. (1988). The learner-centered curriculum. Cambridge: Cambridge University Press.

Oxford, R. (1990). Language Learning Strategies: What every teacher should know. University of Alabama. Newbury House Publisher.

Peveto,C. (1997). Constructive design principle. Retrieved from http:// gramma, is.tcu.edu / cpeveoto/ treatise /design html.

Richards, J. C. and Rodgers, T. S. (2001). Approaches and methods in language teaching. Cambridge: CUP.

Schwier, R. A. (1995). Issues in emerging interactive technologies. In G. Anglin (Ed.), Instructional technology: past, present, future (2nd ed.), pp. 119-130. Englewood, CO: Libraries Unlimited.

William, M., \& Burden ,L.(1997). Psychology for language teacher. Cambridge: CUP. 